\title{
Rozumění pedagogickému jsoucnu: k duchovní obnově pedagogiky a škol ${ }^{1}$
}

\author{
Lumír Ries \\ Ostravská Univerzita v Ostravě, Pedagogická fakulta, Katedra pedagogiky primárního \\ a alternativního vzdělávání
}

\begin{abstract}
Abstrakt: Pedagogické jsoucno jako veškeré pedagogické dění má vzhledem k současné situaci člověka a jeho světa doznat hlubokých proměn. Rozumění povaze hierarchické struktury pedagogického jsoucna je možným předpokladem těchto proměn. Hierarchická struktura je tvořena těmito sedmi rovinami: 1. náprava věcí lidských; 2. mezilidské vztahy; 3. specifikum oblastí poznávání a konání; 4. vázanost oblastí poznávání a konání; 5. kulturní, filosofické (světonázorové) potence poznávání a konání; 6. poznávání a prožívání smyslu, vyšších hodnot, spirituality; 7. činy, jednání, chování, užití. Předpokladem žádoucích proměn edukace je základová první rovina a vrcholové roviny pátá až sedmá.
\end{abstract}

Klíčová slova: roviny pedagogického jsoucna, proměny edukace, poslání (mise) pedagogiky a školy, vůle konat dobro

\section{Slovo úvodem}

Celostním pedagogickým jsoucnem budeme zde rozumět veškeré dění (jeho aktéry a předmětnosti), které unese atribut pedagogické, tedy mající vztah k výchově-vzdělání, k edukaci. Ve shodě s Eugenem Finkem budeme jsoucnu a jsoucímu rozumět v tomto smyslu:

Základnípostoj, který ovládáa nese nejen všedníden člověka v jeho bezprostředním zacházení s věcmi, ale také reflektované způsoby našeho rozumění bytí, je vydanost jsoucímu. Jsme jsoucím zaujati - a zajati. Všechno, co děláme, a od čeho upouštíme, oč usilujeme, před čím prcháme, co milujeme, nenávidíme, poznáváme a víme, to všechno je v nějakém smyslu jsoucno. Svět je pro nás plný jsoucího. I my sami jsme jsoucnem a jsme obklopeni a obklíčeni jiným jsoucím hojného druhu. Naše rozumění je především rozuměním jsoucímu. (Fink, 1996, s. 129)

Celostní pedagogické jsoucno je vlastně prostorem celé řady jsoucen. Je to alespoň pedagogická teorie, nauka a její produkce; tvorba učebnic a vyučovacích prostředků; rozsáhlé školní edukační dění a jeho vazba na rodinu, na při-

1 Základem této stati je referát na mezinárodní vědecké konferenci Studia Humanitatis - Ars Hermeneutica. Konferenci pořádala Filosofická fakulta Ostravské univerzity 9.-10. 5. 2012. 
školní komunitu a školskou administrativu; výchova v rodině; pregraduální a postgraduální vzdělávání učitelů a vychovatelů; činnost profesních organizací a asociací učitelů. $\mathrm{V}$ tomto našem pojednání bude v popředí pedagogická teorie, nauka a školní edukační dění.

Chtěli bychom zde představit názor, že pedagogické jsoucno má vzhledem k současné situaci člověka a jeho světa doznat hlubokých proměn, obratu, po němž volají oprávněně radikálně kriticky a humanisticky uvažující myslitelé, jakými byli a jsou - nahlíženo od Západu na Východ - P. Freire, H. Röhrs, R. Palouš, B. Suchodolski, Š. Amonašvili, K. Obara a jiní.

Jednou z cest, jak rozumět těmto žádoucím proměnám, tomuto obratu, je podle našeho soudu rozumění povaze, uspořádanosti pedagogického jsoucna, jeho struktuře: co je v něm základem, jaká je optimální hierarchie jeho úrovní, vše s ohledem na nápravu věcí lidských, máme-li se přidržet slov Komenského, jehož Obecná porada o nápravě věcí lidských - De rerum humanarum emendatione consultatio catholica - zůstává nepřekonanou, nenaplněnou geniální vizí, projektem sociálních a pedagogických proměn ve prospěch člověka a jeho světa.

Námi postulovaný konstrukt sedmi rovin stupňovité, „pyramidální“ hierarchické struktury pedagogického jsoucna je předmětem tohoto pojednání (schematické znázornění na obr. 1). Tento konstrukt nevznikl pouze jako výsledek pedagogické logické argumentace, ale jako svého druhu obraz, na jehož sestavení se podílela pedagogická intuice. Přihlašujeme se totiž ve vší skromnosti $\mathrm{k}$ těm pedagogickým tvůrcům, kteří vědění o výchově, vzdělání, edukaci vytvářeli v jednotě (pedagogické) filosofie, (pedagogické) vědy a (pedagogického) umění. ${ }^{2}$

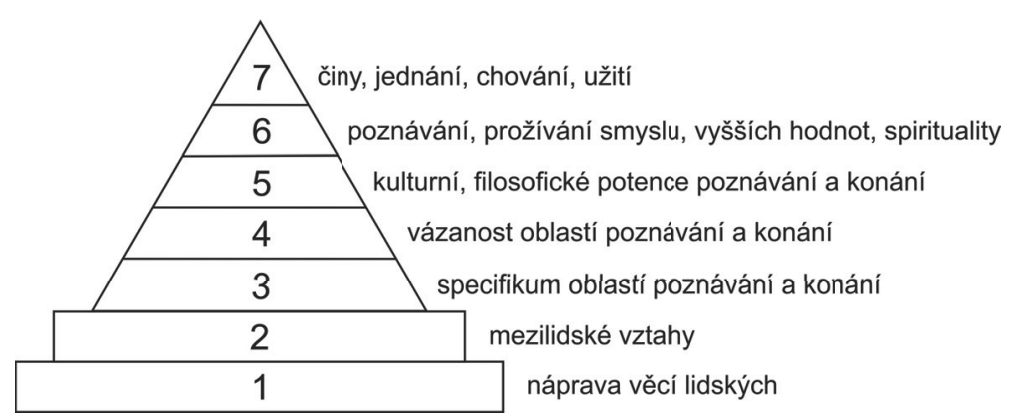

Obrázek 1. Struktura pedagogického jsoucna.

2 Podrobněji o tom jsme pojednali na jiném místě (Ries, 2011, s. 6-40). 


\section{První rovina: Náprava věcí lidských}

Je to základová rovina pedagogického jsoucna, jeho konceptuální rámec.

Pravděpodobně nikdo před Komenským a nikdo po Komenském nezaložil poslání, misi výchovy-vzdělání na tak širokém, rozsáhlém sociálním základě. U všech velkých reformních pedagogických myslitelů novověku (Rousseaua, Pestalozziho, Tolstého, Deweye, Steinera, Montessori a dalších) byl nejsilnějším motivem jejich projektů motiv antropologický - jak pomoci výchovouvzděláním člověku. Avšak sociální kontext a v něm humánně existenciální stav člověka nebyl nikde domyšlen do takových filosofických, pedagogických, duchovních podrobností jako v Komenského Obecné poradě.

Pampaedii - Univerzální vzdělávání - jako čtvrtý ze sedmi dílů tohoto veledíla lze považovat za vlastní vyvrcholení Komenského pedagogické tvorby. Pampaedia je „vsazena“ mezi šest dalších dílů, počínaje Všeobecným probouzením a Všeobecným osvícením a konče Všeobecnou nápravou a Všeobecným povzbuzením. Pokud jde o široce chápaný obsahový zřetel edukace, je Pampaedia jako teorie univerzálního vzdělávání vázána na velkoryse vytvořený nejrozsáhlejší třetí díl Obecné porady, na hluboce pojatou Pansofii - Všeobecnou moudrost.

Pansofia zaujímá větší polovinu Obecné porady, víc než ostatních šest dílů dohromady. Je to rozsáhlý a hluboký základ onoho podivuhodného díla, tvořící podle Dagmar Čapkové samostatnou soustavu poznání o řádu, celku světa. Má osm částí, „, které autor nazývá grady, tj. stupně nebo světy, vrstvy kosmického harmonicky uspořádaného celku..." Jde o pojetí vývojového dramatu kosmu, jednotlivých vrstev jsoucna, „od dokonalého světa po stvoření, přes pád, pokažení světa k světu hmotné př́rody, ale odtud opět vzestupně světem lidské činnosti, morálky a náboženství k nové duchovní dokonalosti“ (Čapková, in Komenský, 1992, I, s. 12). Je to - slovy Komenského - všechno myšlené, vyslovené a konané, které se různým způsobem kombinuje. Když autor nazývá tento díl Pantaxií, chce tím zdůraznit přísnou uspořádanost, systematičnost veškerého vědění, které představuje.

Pro Jana Patočku je Obecná porada dílo konstruktivního racionalismu a neortodoxní teologie. Metodická „reforma Descartova se Komenského nedotkla a dotknout nemohla, poněvadž stojí na opačném pólu proti kartesiánskému subjektivismu v pojetí pravdy, který se mu jeví extrémem té nepravosti, z níž 
pramení všechny naše zmatky a bědy: snahy být si sám vlastním středem“ (Patočka, in Komenský, 1992, III, s. 560).

Pro současnou pedagogiku je Obecná porada bohatou studnicí inspirací a dosud neslyšených, nenaplněných podnětů, má-li se přihlásit k poslání napomáhat nápravě věcí lidských. Musí se přitom vypořádat z hlediska současného poznání a vědění o člověku a společnosti s námitkami utopie, utopismu, a to bez předsudků různých reliktů pozdního pozitivismu a jiných podob omezeného scientismu.

Pro vědění o výchově, o edukaci je věcí zásadní důležitosti rozlišovat mezi utopií a vizí nebo projektem. Obecně nahlíženo je utopie často vznešenou, nicméně pohodlnou výmluvou. To platí i o možných pedagogických utopiích. Rozumějme tedy pedagogické vizi, pedagogickému projektu na rozdíl od utopie tak, že vize, projekt je meta, k níž se lze přibližovat nebo jí lze za určitých podmínek dosáhnout, rozumíme-li člověku v jeho neredukované celosti, přiznáme-li mu spolu s tělesnem a duševnem duši, schopnost jak tělesného a duševního konání, tak i duchovní, spirituální transcedence.

Jan Patočka odmítal názor, že Komenského nápravné sociální a pedagogické vize jsou utopie: „Zdůrazňuji název projekt na rozdíl od utopie; není to ideální obraz vytvořené společenské skutečnosti, nýbrž návrh na nápravu poměrů skutečného lidstva na podkladě celkového pojetí smyslu a směru dějinného vývoje“ (Patočka, in Komenský, 1992, III, s. 533).

Jednou ze skutečností svědčící o tom, že Obecná porada není utopií, ale vizí, projektem, je to, že je myšlena a psána jako též společenská, politická výzva, výzva k všeobecné poradě (consultatio catholica), k níž by přistupovala světla Evropy, významné osobnosti, které mají $\mathrm{k}$ nápravě věcí lidských co říci. ${ }^{3}$ Právě obrácení k takovému všeobecnému diskurzu je jedním z velkých dluhů dnešní pedagogiky. Pedagogika není (též) politikum, nedokáže, spíše nechce vycházet ze své odborné uzavřenosti.

To, co je konáno na půdě mezinárodních organizací, je velmi záslužné, ale je toho dosud málo a především plody různých dosavadních aktivit jsou zanedbatelné. Jako výrazně humánně orientovaný dokument o nápravě školy a edukace může sloužit zpráva Mezinárodní komise UNESCO Vzdělávání pro 21. století z roku 1996 (Delors, 1997). Je to projekt edukace založený na

3 V mottu je citováno z Přísloví 15, v. 22: „Bez společné porady přicházejí myšlenky nazmar, kdežto při větším počtu rádců se utvrzují." 
„čtyřech pilíŕích“, jimiž jsou: učit se poznávat - učit se jednat - učit se žít společně s druhými - učit se být.

Nicméně většina mezinárodních i národních oficiálních dokumentů o vzdělávání je svou povahou stále převážně pragmaticky zaměřena, nedosahující na horizont nápravy věci lidských v hlubokém duchovním smyslu. Situaci pedagogiky vyjádřil velmi lapidárně psycholog Zdeněk Helus:

Pedagogika si dosud počíná jako by se - krize nekrize - nic moc nedělo, pročež dělejme, co a jak jsme zvyklí... Mnohé ale nasvědčuje, že něco převratného se děje, něco co je třeba vzít s veškerým pedagogickým umem a veškerou pedagogickou kuráží do úvahy. (Helus, 2012, rukopis)

Tu se setkáváme s pojmem krize. První námi postulovaná rovina pedagogického jsoucna - náprava věcí lidských - je jako základna a konceptuální rámec celé struktury předpokladem takových proměn pedagogického dění, aby se pedagogika a škola uměla vyrovnávat s existujícími společenskými, mravními, pedagogickými symptomy krize.

Komenský dokáže vedle složitých sofistikovaných výkladů antropologického fenoménu věcí lidských dát čtenáři i tento jednoduchý, výstižný výměr: „Nyní tedy bude mezi námi jasno, co jsou lidské věci: bezesporu moudrost mysli, zbožnost srdce a klid životní; a ty jsou získány filosofií ${ }^{4}$, náboženstvím a politikou" (Komenský, 1992, I, s. 84).

\section{Druhá rovina: Mezilidské vztahy}

Zatímco první rovina byla rovinou ve vztahu k pedagogickému dění, zvláště ke školní edukační realitě zdánlivě vnější, externí, je tato druhá rovina, kterou taktéž pokládáme za základovou, zřetelně vnitřní, interní rovinou.

Máme tedy představu dvojího základu pedagogického jsoucna, vycházející z názoru, že mezilidské vztahy jsou alfou a omegou výchovy, což se týká na prvním místě vztahu učitele a žáka. Někteří myslitelé charakterizují výchovu zcela krajně: výchova je vztah. Pro jiné je základem všech základů výchovy láska (Pestalozzi). Pedagogika zná pojem pedagogická láska. Dnes se častěji píše o prosociálnosti nebo prosociálnosti založené na lásce (Roche Olivar).

\footnotetext{
4 Filosofií je u Komenského myšleno širší teoretické vědění, tedy i věda.
} 
V prostoru pedagogického dění jsou i další významné vztahy: žáků navzájem; učitelů navzájem; učitele/učitelů a rodiče/rodičů; učitele/učitelů a činitelů přiškolní komunity (obce).

Ve srovnání s první rovinou je oblast mezilidských vztahů ošetřena rozsáhlou psychologickou a pedagogickou literaturou a je předmětem pregraduálního i postgraduálního studia učitelů a vychovatelů. Nicméně jak v učitelské, tak v široké veřejnosti je v současnosti realizace láskyplného vztahu učitele a žáků nahlížena jako velmi nesnadná. Řeší se naopak otázky agresivity, šikany, a to i šikany učitelů (učitelek) ze strany žáků.

Některé alternativní školy - např. waldorfská škola - se s touto otázkou vyrovnávají uspokojivě. (Zpravidla to souvisí i s dobře nastaveným vztahem školy a rodiny.) Soudíme, že je tomu tak proto, že pedagogika těchto alternativ sdílí názor, že úkolem školy je starost o nápravu věcí lidských (naše první rovina) a že jsou tam respektovány vrcholové roviny (zde pátá, šestá a sedmá), o nichž bude dále řeč.

\section{Třetí rovina: Specifikum oblastí poznávání a konání}

V situaci, kdy školní vzdělávání se realizuje převážně v určitých vyučovacích předmětech, je otázka tohoto specifika otázkou cílů, obsahu a metod vzdělávání v určitých vyučovacích předmětech. Současná pedagogika je zaměstnána především didaktickými otázkami tohoto vzdělávání. Nutno říci, že jak na obecné úrovni (obecná didaktika s pomocnými vědami), tak na úrovni jednotlivých předmětů (oborové didaktiky s pomocnými vědami) jde o nejkvalitnější součást pedagogického jsoucna, a to jak v oblasti teoretického bádání, tak ve vzdělávací praxi.

Jako příklad progresivního didaktického konceptu uved'me alespoň orientaci na kreativnost (Maňák, 1998) nebo konstruktivistické pojetí (Štech, 1992) s důrazem na autentičnost poznání. Žák/student je subjektem tvorby poznatků: má hledat, objevovat a konstruovat poznání vlastní činností, přičemž základem jsou mu osobní zkušenosti, prožitky, jejich interpretace.

Pokud jde o kreativní učební činnosti, je podnětné Aristotelovo rozlišování tř́i oblastí činnosti: teorie, praxe, poiesis. Činností praktickou se myslí jednání, které má hodnotu samo v sobě, např. jednání mravní. Činnost poietická je zaměřena na to, co je vytvářeno, tedy na dílo: at' je povahy řemeslného konání, nebo umělecké tvorby (Anzenbacher, 1990, s. 193). 


\section{5 Čtvrtá rovina: Vázanost oblastí poznávání a konání}

Rozdělení vzdělávání - vědeckého, uměleckého, jazykového, pracovního - do jednotlivých vyučovacích předmětů je jednou z příčin, že poznání jisté celosti světa, lidského bytí, lidských aktivit v něm jako určitý možný předpoklad utváření názoru na svět a na sebe sama je v praxi škol nenaplněným programem. Je známo, že nechybí požadavek tzv. mezipředmětových vztahů, ani určitá pedagogická teorie této věci; ta však převážně trpí nízkou filosofickou úrovní. Jde totiž o nikoliv snadný, svrchovaně filosofický náhled na daný fenomén. Zúžené didaktické chápání, vedoucí nezřídka k náhodně vybraným kognitivním faktům, věc neřeší.

Když Fink představuje svět jako krajinu všech krajin vůbec, rozvíjí tuto myšlenku takto:

Svět je tím obchvacujícím a všechno zahrnujícím prostorovým a časovým celkem. Všechny prostory jsou v něm a stejně tak všechny časy. Světový prostor obsahuje všechna místa a všechny v prostoru rozprostřené věci, světový čas pojímá do sebe všechny časy a všechny chvíle, trvání a změny všech nitročasových věcí. Časoprostor světa je ta nejvíce obchvacující krajina všeho bytí jsoucího. (Fink, 1996, s. 135)

Vzápětí však problematizuje myšlenku celku světa: „Co se ale skutečně myslí, když řekneme, že svět je celkem? Jaká představa o celku nás při tom vede? Máme vůbec nějakou jasnou a zřetelnou představu, co znamená celost světa?" (Fink, 1996, s. 135)

\section{Pátá rovina: Kulturní, filosofické (světonázorové) potence poznávání a konání}

Učitelovo, žákovo/studentovo nalézání kulturních, filosofických, světonázorových potencí toho, co je poznáváno, konáno, ovládáno, je dalším stupněm na cestě edukace vedoucí k pravému lidství.

Kultuře, fenoménu, který má desítky pojetí, interpretací, vymezení zde chceme rozumět v Šaldově pojetí a rozlišovat mezi kulturou a civilizací: civilizace jako hmotný, strojový pokrok, něco vnějšího; kultura jako vnitřní zušlecht'ování, utváření osobnosti s dominací formy, nikoliv látky, element kázně a řádu (Goethe). Cílem kultury je vyšší řád lidstva, řehole lidské duše, spění k nekonečnu. Kultura jako kázeň je něčím aristokratickým, je to nový aristokratismus - otevřený, nikoliv výlučný, dědičný. 
Protikladem člověka jako osobnosti niterné kultury je v této civilizaci filistr (Nietzschův Bildungsphilister), člověk, „který nikdy nežije skutečně ve vlastní osobě, nýbrž z druhé ruky, stínem: pozorováním, dohady, logickou dedukcí, soudem, nikdy ne vlastní zkušeností“, opatrník a rozšafník, „,který se vědou a civilizací pojišt'uje proti životu a jeho nevyzpytatelnosti“, fanatik matematického a statistického, který každou kvalitu převádí a překládá v kvantitu, je tedy v roli „životního a kulturního př́živníka a ne dělníka, výrobce, ne tvůrce - nebot’ mezi těmi třemi jest hluboké vnitřní spříznění a konečné sjednocení" (Šalda, 1948, s. 27).V tom smyslu rozumějme nalézání kulturních potencí poznávání a konání v průběhu vzdělávání.

Pokud jde o filosofii, v porovnání s vědou, kterou si člověk jako předmět vzdělávání „osvojuje“, tedy ji posléze má (nebo nemá), není filosofie věcí mětí, nýbrž je oblastí bytí, patří podle Finka „k podstatě člověka. Nepřebýváme mimo ni - nemáme žádné místo, které by bylo zcela prosto její moci, jejího vábení a její hrozby. Jakmile člověk vystoupí z přírodního míru zvířete do volného prostoru svobody a obývá zemi tak, že mluví a rozumí, nazývá věci jsoucím, je zasazen do oblasti moci filosofie“ (Fink, 1996, s. 21).V tom smyslu lze rozumět nalézání filosofických potencí veškerého poznávání a konání, nikoliv ve smyslu filosofování, pěstování (akademické) filosofie.

Co žák - dítě, mladý člověk - poznává a prožívá z věd, umění, světa práce, čím jej oslovují osudy lidí, etnik, národů, zvláště osudy významných osobností z nejrůznějších oblastí lidské činnosti, má působit na jeho utváření názoru na svět, na jeho světonázorové zrání ve smyslu výše nahlédnuté kultury a filosofie. To se netýká jen vzdělávání v literatuře, umění nebo v humanitních vědách. Připomeňme alespoň, že do výuky matematiky, fyziky, astronomie, chemie, biologie mohou vedle vědy samé vstupovat i životy, životní osudy vědců, objevitelů - Pythagora, Euklida, Newtona, Lobačevského, Mendělejeva, Pasteura, Einsteina, Ciolkovského a jiných. Hájení poznané pravdy, mravní postoje některých vědců vedly až k jejich krutému pronásledování. Giordano Bruno byl upálen středověkou inkvizicí, Andrej Sacharov pronásledován, vypovězen sovětskou ideologickou zvưlí. Přírodovědě blízká je medicina. Žáci, studenti se mohou dovědět, že mezi velké osobnosti teorie a praxe výchovy patřili altruisticky smýšlející lékaři - Claparède, Decroly, Montessori, Pirogov a další. Lékař, spisovatel, pedagog-umělec Janusz Korczak neopustil své svěřence, židovské sirotky a odešel s nimi na smrt do koncentračního tábora v Treblince. Během životopisných exkurzí, které mohou být i rozhovory, diskusemi, žáci, studenti nepoznávají jen názory vědců na člověka, svět, vesmír, společnost, ale také světonázorové postoje svého učitele. 


\section{7 Šestá rovina: Poznávání a prožívání smyslu, vyšších hodnot, spirituality}

0 všech rovinách pedagogického jsoucna, jak je zde představujeme, platí, že jsou mezi nimi významné vztahy. Zvlášt' významným znakem v hierarchickém uspořádání rovin pak je to, že nižší roviny obsahují nějak něco $\mathrm{z}$ rovin vyšších. Tato skutečnost je obzvlášt' zřetelná v těsném vztahu mezi pátou a šestou rovinou. Co je v páté rovině reflektováno a prožíváno, nabývá v šesté rovině další niterné hloubky.

Výchova-vzdělání, edukace má být ozvláštňováním života - překračováním všednodennosti. Podle Kühlewinda má všednodennost alespoň tyto dva znaky: automatismus, tedy neosobnost, sociálně zavedené zvyklosti a předsudky na straně jedné, sebestřednost, individuální egoistické jednání na straně druhé (Kühlewind, 2010, s. 73). Každá oblast poznání a konání, každý vyučovací předmět může překonávat všednodennost žákova života svou specifickou zvláštností, nevšedností, vzácností, a tím ozvláštňovat jeho život.

Jak se to děje? Nejen vědomě, racionálně, ale též vhledem, nevědomě, intuicí, jestliže svět daného poznání nebo konání - vyučovacího předmětu - nese v sobě, „nad sebou“ podněty ozvláštňování všednodennosti. Na rozdíl od Freuda i Junga, pro něž je nevědomí podvědomím, postuluje Kühlewind fenomén nadvědomí.

Racionálno může pocházet jen z pramene světla, který je silnější než ono samo (...) Nadvědomý pramen racionálního vědění - duchovní svět - neodkryli ani racionalisté, ani iracionalisté. Vědění o něm hrálo od středověku jen skrovnou roli na okraji kulturního života. Mystikové, ojedinělí filosofové, básníci - vůbec umělci - ho intuitivně zachycovali, ale jejich vědomí nedokázalo proniknout „život“, každodenní život. (Kühlewind, 2010, s. 45)

Dnešní převažující situace člověka je taková, že toho, co člověku nejvíce chybí, si vůbec nevšimne. Ví o vnějším nebezpečí, o hrozícím nedostatku energie a surovin, o poškozování životního prostředí a nesmyslném ekonomickém růstu, o neřešených otázkách atomové energie nebo pesticidů atd. „Na to všechno může lidstvo zahynout, ale za těmito jevy leží skrytý hlubší, základnější nedostatek: vyhasínání velkých intuicí, které kdysi člověku - zčásti nevědomě - umožňovaly orientovat se v jeho postavení ve vesmíru“ (Kühlewind, 2010, s. 27). 
Psycholog, myslitel Kühlewind operuje s pojmem morální intuice, který je pro naše téma podnětný. Duchovní, spirituální výchově může být rozuměno jako (stavu) napětí mezi všedním člověkem a životním úkolem platónského světla a - v naší kultuře - křest’anského až „nemožného“ milování nepř́ítele. V tomto napětí se podněcuje, živí, posiluje, roste morální, duchovní intuice, a to především vědomou a nevědomou imaginací.

Žák/student si klade otázky po smyslu: smyslu toho, co poznává, co koná; partikulární otázky po smyslu jej přivádějí k otázce po smyslu života - svého, svých blízkých, lidí vůbec. Jinak nahlíženo, hodnotí, co je v jeho světě a světě, který je mu dostupný, významné, žádoucí, pravdivé, dobré, krásné, nebo naopak nevýznamné atd., ocitá se v prostoru hodnot. Výchova-vzdělání, edukace napomáhá spolu s životními zkušenostmi mimoškolními jeho růstu v tomto pro život velevýznamném prostoru. Je si přát, aby současná a budoucí škola byla místem, které by dítěti, mladému člověku poskytovala pomoc směřující k poznání a prožívání vyšších hodnot - existenciálních, etických, estetických, spirituálních.

Jezuita a zenový mistr H. M. Enomiya-Lassalle by o tom řekl, že je třeba žákům pomáhat otevírat třetí zrak. $V$ opoře o křestáanskou mystiku a také Plotina se zmiňuje o trojím zraku: zraku smyslovém, zraku rozumu a zraku kontemplace. Pokud jde o současnost, první, smyslový zrak zůstal zachován, druhý, zrak rozumu, je však zatemněn a zrak třetí, zrak kontemplace je zcela oslepen. „Je třeba učinit tento zrak znovu vidoucím“ (Enomiya-Lassalle, 1995, s. 83).

Spirituální zřetel výchovy není něčím, čím by česká pedagogika a škola oplývala. Takže studie Pavla Říčana v časopise Pedagogika Spiritualita jako základ mravní výchovy je $\mathrm{v}$ našem pedagogickém jsoucnu událost dosti vzácná. Přitom sám název pojmenovává svého druhu axiom mravní výchovy. A v mravně značně pokleslé společnosti je i významnou výzvou pro pedagogiku a školu. Spiritualita není autorem ztotožňována s náboženstvím. Jde o přesažné, transcendentní hodnoty, jejichž přijetí a prožívání má významný vliv na vztah $\mathrm{k}$ sobě, druhým lidem, $\mathrm{k}$ přírodě, $\mathrm{k}$ tomu, co člověk považuje za nejvyšší. Z psychologického hlediska to mohou být „prožitky reflektované jako soucit, láska, slušnost, hrdinství, výčitky svědomí, touha po spravedlnosti, radost pomoci druhým - i utrpení pro pravdu atd." (Říčan, 2006, s. 126). Podle Elkinse a spolupracovníků, na něž se autor odvolává, lze chápat jako složky spirituality transcendentní dimenze, jistotu smyslu života, 
altruismus, nezávislost na materiálních hodnotách, vědomí tragičnosti lidské existence. Odvolává se též na Fromma (na jeho potřebu systému orientace a oddanosti, uctívání); na Koháka (vědomí rozměru posvátnosti); na Maslowa (spirituální potřeba kosmické identifikace; to, co je nám svaté).

Výchozím předpokladem „otevírání třetího zraku“ je, aby filosofickoaxiologické a spirituální aspekty byly významnou součástí pedagogického jsoucna, aby našly odpovídající prostor v pedagogické teorii, pedagogickém bádání a publikování. Jak bylo řečeno výše, má se pedagogika a škola angažovat společensky, politicky: aby věci proměny vzdělávání, výchovy, školy v situaci, kdy školství řídí, spravují státní a veřejné instituce, byly tyto instituce získávány pro dané proměny. Vyžaduje to i rozsáhlou pedagogickou osvětu, nebot' o proměnách musí být informována a s proměnami souhlasit široká veřejnost. Nelze se ovšem neobávat, že špatně fungující demokracie bude jen obtížně zvládat tento úkol $\mathrm{v}$ životně nad jiné důležité oblasti společnosti.

Hovoříme-li zde o předpokladech toho, aby filosoficko-axiologické a spirituální aspekty byly významnou součástí pedagogického jsoucna, nepomineme ani samozřejmost, že klíčovým předpokladem pro to je učitel, osobnost učitele, jeho niterná kultura, filosofie, jak o tom byla řeč výše; a tedy též jeho vzdělávání a vzdělanost. Prozatímní systém pregraduálního vzdělávání tomuto předpokladu neodpovídá; ani způsobem výběru uchazečů o toto studium, ani obsahem teoretického studia, ani nedostatečností praktických a poietických činností. Hlavní nedostatek lze pojmenovat jako nedocenění filosoficko-antropologického a filosoficko-etického aspektu vzdělávání a vzdělanosti učitelů. ${ }^{5}$ Aby učitel - právě tak literární výchovy jako přírodopisu nebo matematiky - rozuměl duchovně mravní výchově jako trojímu niternému pohybu: výše nad sebe, hlouběji do svého nitra, blíže k druhému, k druhým.

Poznámka k tomu: Několik let jsem ve svém semináři dával studentům (vlastně studentkám budoucím učitelkám primární školy) dotazník, v němž se několik otázek týkalo přímo nebo nepř́mo hodnot. Jakkoliv odpovědi nebyly často sebereflexí, nýbrž sebestylizací (snahou ukázat, že nesdílejí hodnoty egoistického, konzumního světa, v němž žijí), jako vyšší, nejvyšší hodnoty byly nejčastěji jmenovány dvě - zdraví a přátelství. Vyšší hodnotový obzor byl výjimečný, a to obyčejně u zřetelně nábožensky orientovaných osob. 


\section{Sedmá rovina: Činy, jednání, chování, užití}

Ve shodě s řadou myslitelů všech dob lze pokládat za ukazatel toho, kým člověk je, činy, které koná, jak jedná, jak se chová, nikoliv znalosti, které má, slova, pravdy, které hlásá. Je-li plodem výchovy-vzdělání, edukace svobodné, zodpovědné rozhodování člověka o dobrých činech, je to žádoucí výsledek edukace. Vůli konat dobro je osobnostní duchovně morální sebeutváření člověka korunováno.

Komenský zavedl do svého pedagogického pojmosloví pojem chrésis - užití - a o trojici teorie - praxe - chrese v Pampaedii V, 30 ř́́ká: „Konečně metoda bude trvale jedna, a to jednoduchá a snadná: vždy začínat od teorie, pak jít k praxi a dospět k chresi“ (Komenský, 1992, III, s. 49).

A v Pansofii X čteme:

Všude přihlížej $\mathrm{k}$ teorii, praxi a užití. $\mathrm{K}$ teorii proto, že podává všechny třídy podstat, př́padků a nedostatků, a to jak ve věcech jednotlivých, tak i podvojných a sdružených. K praxi proto, abys dovedl počítat, měřit, vážit. K užití proto, abys volil dobro a odmítal zlo. (Komenský, 1992, I, s. 292)

Chrese, užití není tedy myšleno pragmaticky (praktické uplatnění), ale především eticky: abys volil dobro a odmítal zlo.

Jakkoliv je současná škola orientována značně pragmaticky, nechybí v teoretické oblasti úsilí zkoumat (finální) podobu edukace jako dobré konání, dobrý život. Zajímavé v tomto ohledu je studium a výzkum fenoménu kvality života dětí a dospívajících vzhledem ke školnímu vzdělávání (Mareš, 2008). Koncept rozvoje kvality života dětí je nahlížen od somatického zrání, přes psychický a sociální rozvoj a rozvoj dětského JÁ po možnosti spirituálního rozvoje (Lukášová, 2010).

\section{Závěr}

Pokus o nástin sedmiúrovňové hierarchické struktury pedagogického jsoucna chce být příspěvkem $\mathrm{k}$ úsilí o reflexi potřeby proměny výchovy-vzdělání, edukace: aby škola přijala a vykonávala poslání, misi pomáhat nápravě věcí lidských. Jak snad vyplynulo ze stručného výkladu, podstatná pro uskutečnění proměny, obratu je první - základová - rovina pedagogického jsoucna (náprava věcí lidských) a tři roviny vrcholové: (5) kulturní, filosofické poten- 
ce poznávání a konání; (6) poznávání a prožívání smyslu, vyšších hodnot, spirituality; (7) činy, jednání, chování, užití. Necht' veškeré pedagogické dění směřuje $\mathrm{k}$ tomu, aby svět člověka se měnil k dobrému tím, že člověku je edukací pomáháno, aby ve své neredukované tělesné, duševní, duchovní celosti měl vůli konat dobro.

Také tento zpětný pohled na hierarchické uspořádání pedagogického jsoucna můžeme na závěr podepřít pohledem na základní pojetí pedagogického konání u J. A. Komenského. Ve Velké didaktice najdeme toto řazení kapitol o metodách: XX. Metoda věd zvlášt', XXI. Metoda umění, XXII. Metoda jazyků, XXIII. Metoda mravů, XXIV. Metoda vštěpování zbožnosti. A v prvním odstavci XXIII. kapitoly o metodě mravů se říká, že vědy, umění, jazyky jsou přípravou pro to hlavní - pro mravy a zbožnost:

Je to totiž pouze příprava $k$ větším věcem... Jsou to pouze naše začátky a ne díla. Co tedy jsou naše díla? Snažení o moudrost, která nás má učinit vyššími, statečnými a velkoduchými. To je právě to, co jsme výše označili jménem mravů a zbožnosti... (Komenský, 1958, s. 199)

\section{Literatura}

Anzenbacher, A. (1990). Úvod do filozofie. Praha: SPN.

Čapková, D. (1992). Obecná porada a její význam. In J. A. Komenský, Obecná porada o nápravě věcí lidských. Sv. I. Praha: Svoboda.

Delors, J. (Ed.). (1997). Učení je skryté bohatství. Zpráva Mezinárodní konference UNESCO „Vzdělání pro 21. století". Praha: PedF UK.

Enomiya-Lassalle, H. M. (1995). Zenová meditace. Brno: Cesta.

Fink, E. (1996). Bytí, pravda, svět. Praha: OIKOYMENH.

Helus, Z. (2012, rukopis). Společenská krize - důsledky pro pojetí edukace jakožto starosti o člověka. In H. Lukášová (Ed.), Proměny pojetí vzdělávání a školního hodnocení. Praha: Asociace waldorfských škol ČR.

Komenský, J. A. (1958). Vybrané spisy Jana Amose Komenského. Sv. I. Praha: SPN.

Komenský, J. A. (1992). Obecná porada o nápravě věci lidských. I., II., III. svazek. Praha: Svoboda.

Kühlewind, G. (2010). Služebníci Slova. Člověk jako slovo a rozhovor. Hranice: Fabula.

Lukášová, H. (2010). Kvalita života dětí a didaktika. Praha: Portál.

Maňák, J. (1998). Rozvoj aktivity, samostatnosti a tvořivosti žáků. Brno: Masarykova univerzita.

Mareš, J. (Ed.). (2008). Kvalita života dětí a dospívajících III. Brno: MSD.

Patočka, J. (1992). Komenského Všeobecná porada. In J. A. Komenský, Obecná porada o nápravě věcí lidských. Sv. III. Praha: Svoboda.

Ries, L. (2011). Člověk a výchova II. K humanizaci školy a edukace. Ostrava: OU, Pedagogická fakulta. 
Říčan, P. (2006). Spiritualita jako základ mravní výchovy. Pedagogika, 56(2), 119-131.

Šalda, F. X. (1948). Studie o umění a básnících. Praha: Melantrich.

Štech, S. (1992). Škola stále nová. Praha: Univerzita Karlova.

\title{
Autor
}

Prof. PhDr. Lumír Ries, Ostravská univerzita v Ostravě, Pedagogická fakulta,

Katedra pedagogiky primárního a alternativního vzdělávání, Dvořákova 7, Ostrava 701 03, e-mail: lumir.ries@ osu.cz

\section{Understanding pedagogical existence: Contribution to the spiritual renewal}

\begin{abstract}
Similarly to all pedagogical activities, in view of the present situation of man and his world, pedagogical existence is expected to undergo profound transformations. Understanding the nature of the hierarchical structure of pedagogical existence is a potential precondition of these transformations. The hierarchical structure contains the following seven levels: 1 . rectification of human circumstances; 2 . interpersonal relations; 3. specificity of the spheres of cognition and behaviour; 4 . interconnection between the spheres of cognition and behaviour; 5 . the cultural, philosophical (ideological) potential of cognition and behaviour; 6. learning and experiencing the meaning, higher values and spirituality, 7. deeds, action, behaviour, utilisation. The first, basic level and the top levels, i.e. from the fifth to the seventh, can be considered preconditions of desirable transformations within education.
\end{abstract}

Keywords: levels of pedagogical existence, transformations within education, mission of pedagogy and schools, the will to do good

Kosová, B. et al. (2012). Vysokoškolské vzdelávanie učitelov. Vývoj, analýza, perspektívy. Banská Bystrica: Pedagogická fakulta UMB.

Publikace systematizuje poznatky o současném stavu přípravy studentů učitelství na výkon učitelské profese na Slovensku, a to na základě domácích a zahraničních výzkumů, mezinárodní komparace, teorie učitelské profese a zpětné vazby ze strany učitelů. Součástí publikace jsou mimo jiné analýza vývoje učitelského vzdělávání a identifikace základních problémů transformace vysokoškolského vzdělávání učitelů, které ústí do návrhu koncepčních změn a opatření nezbytných pro zkvalitnění vzdělávání učitelů. 